Article

\title{
How Does Pyridoxamine Inhibit the Formation of Advanced Glycation End Products? The Role of Its Primary Antioxidant Activity
}

\author{
Rafael Ramis ${ }^{1,2} \mathbb{D}^{\mathbb{D}}$, Joaquín Ortega-Castro ${ }^{1,2} * \mathbb{D}$, Carmen Caballero ${ }^{1,2}$, Rodrigo Casasnovas ${ }^{1,2}$ (D), \\ Antonia Cerrillo ${ }^{1,2}$, Bartolomé Vilanova ${ }^{1,2} \mathbb{D}$, Miquel Adrover ${ }^{1,2}\left(\mathbb{D}\right.$ and Juan Frau ${ }^{1,2}(\mathbb{D}$ \\ 1 Institut Universitari d'Investigació en Ciències de la Salut (IUNICS), Departament de Química, \\ Universitat de les Illes Balears, 07122 Palma de Mallorca, Spain \\ 2 Institut d'Investigació Sanitària Illes Balears (IdISBa), 07120 Palma de Mallorca, Spain \\ * Correspondence: joaquin.castro@uib.es
}

Received: 24 July 2019; Accepted: 22 August 2019; Published: 1 September 2019

check for updates

\begin{abstract}
Pyridoxamine, one of the natural forms of vitamin $\mathrm{B}_{6}$, is known to be an effective inhibitor of the formation of advanced glycation end products (AGEs), which are closely related to various human diseases. Pyridoxamine forms stable complexes with metal ions that catalyze the oxidative reactions taking place in the advanced stages of the protein glycation cascade. It also reacts with reactive carbonyl compounds generated as byproducts of protein glycation, thereby preventing further protein damage. We applied Density Functional Theory to study the primary antioxidant activity of pyridoxamine towards three oxygen-centered radicals $\left(\bullet \mathrm{OOH}, \bullet \mathrm{OOCH}_{3}\right.$ and $\left.\bullet \mathrm{OCH}_{3}\right)$ to find out whether this activity may also play a crucial role in the context of protein glycation inhibition. Our results show that, at physiological $\mathrm{pH}$, pyridoxamine can trap the $\bullet \mathrm{OCH}_{3}$ radical, in both aqueous and lipidic media, with rate constants in the diffusion limit $\left(>1.0 \times 10^{8} \mathrm{M}^{-1} \mathrm{~s}^{-1}\right)$. The quickest pathways involve the transfer of the hydrogen atoms from the protonated pyridine nitrogen, the protonated amino group or the phenolic group. Its reactivity towards $\bullet \mathrm{OOH}$ and $\bullet \mathrm{OOCH}_{3}$ is smaller, but pyridoxamine can still scavenge them with moderate rate constants in aqueous media. Since reactive oxygen species are also involved in the formation of AGEs, these results highlight that the antioxidant capacity of pyridoxamine is also relevant to explain its inhibitory role on the glycation process.
\end{abstract}

Keywords: pyridoxamine; DFT; AGEs; inhibition; ROS

\section{Introduction}

Protein glycation involves a sequence of nonenzymatic reactions between proteins and sugars. The pathological complications of diabetes (kidney diseases [1], retinopathies [2], vascular diseases [3] and neurodegenerative diseases [4]) are directly related to the effects of these reactions on the structure and function of the affected proteins. The general mechanism of protein glycation starts with the addition of a nucleophilic group of a protein to the carbonyl group of glucose to form a Schiff base, which can subsequently yield an $\alpha$-ketoamine known as an Amadori compound. Schiff bases and Amadori compounds can slowly and irreversibly evolve towards the so-called advanced glycation end products (AGEs) through a heterogeneous set of reactions [4-6].

AGEs can also be generated by several side reactions that occur in parallel to the general mechanism. These generally consist of metal-catalyzed oxidations of Schiff bases or Amadori compounds that yield reactive oxygen species (ROS) and reactive carbonyl species (RCS). Since ROS and RCS are much more reactive than glucose, their ability to damage proteins is much higher, as they enhance the number and type of AGEs that are formed [6-9]. 
Given the pathological implications of protein glycation, the design of molecules with the ability to attenuate its effects is a matter of utmost concern. The three main mechanisms by which these molecules, known as protein glycation inhibitors, prevent the formation of AGEs are: (i) the complexation of metal ions that catalyze the secondary reactions of protein glycation; (ii) the scavenging of RCS; and (iii) ROS generated as byproducts of those secondary reactions. In 1999, it was discovered that pyridoxamine (PM) had the ability of inhibiting the oxidation of Amadori compounds to form AGEs [10]. PM is one of the three natural forms of vitamin $\mathrm{B}_{6}$, together with pyridoxal (PL) and pyridoxine (PN). By that time, it was known that PM was very reactive towards carbonyl groups, since it acted as a coenzyme in transamination reactions between carbonyl compounds and amino groups [11], and this led to consider that it could be an effective AGE inhibitor. Thus far, several studies in both animal and human models have shown its therapeutic effects on diabetic kidney disease [12,13], as well as on retinopathies [14] and vascular diseases [15].

Concerning its mechanism of action, it has been suggested that PM could be effective as a metal chelating agent, a RCS scavenger and/or a ROS scavenger. It can form stable complexes with $\mathrm{Cu}^{2+}$ and $\mathrm{Fe}^{3+}[16,17]$ and stable adducts with several dicarbonyl compounds [18-21], as well as inhibit the production of the hydroxyl radical from the Fenton reaction or directly react with it [22-24]. Some studies also suggest that it can eliminate the superoxide radical anion from the medium [25], while others dispute this conclusion [24].

There exist several experimental assays to evaluate the antioxidant activity of molecules [26,27], but they neither distinguish between oxidant species nor allow the determination of the preferred mechanisms and reaction sites. For these reasons, theoretical methods such as DFT are particularly well suited to assess antioxidant activities. Some DFT studies on the reactivity of PN, another form of vitamin $\mathrm{B}_{6}$, towards hydroxyl, hydroperoxyl and superoxide were carried out by Matxain and coworkers $[28,29]$. Galano et al. also studied the antioxidant capacity of many different organic molecules by using this methodology [30-34].

Here, we aimed to study the ability of PM to scavenge ROS and to determine its preferred mechanisms and reaction sites by applying DFT. This would allow us to complete our previous studies on the formation of complexes between PM and $\mathrm{Cu}^{2+} \mathrm{Or} \mathrm{Fe}^{3+}$ [35-37] and on its reactivity towards RCS $[16,18,38,39]$ in the context of AGE inhibition. Specifically, thermodynamic and kinetic data were computed for all reaction paths between PM and the hydroxyl $(\bullet \mathrm{OOH})$, methylperoxyl $\left(\bullet \mathrm{OOCH}_{3}\right)$ and methoxyl $\left(\bullet \mathrm{OCH}_{3}\right)$ radicals, as well as their branching ratios (that is, the contribution of each path to the overall reactivity of PM). These radicals were chosen because using a highly reactive one such as hydroxyl could lead to the conclusion that all reaction paths are equally likely $[40,41]$. Three different mechanisms were studied: hydrogen-atom transfer, radical-adduct formation and single-electron transfer.

\section{Materials and Methods}

The quantum mechanics-based test for overall free radical scavenging activity (QM-ORSA) methodology, as explained by Galano et al. [42], was applied to compute the rate constants of the reactions between $\mathrm{PM}$ and the $\bullet \mathrm{OOH}, \bullet \mathrm{OOCH}_{3}$ and $\bullet \mathrm{OCH}_{3}$ radicals. Briefly, the geometries of PM and each radical, as well as the reaction products and transition states (TSs), were optimized at the M05-2X/6-311+G(d,p) level of theory. The unrestricted formalism was applied to open-shell systems, and the ultrafine integration grid was used in all the calculations. The M05-2X functional was designed for thermochemistry, thermochemical kinetics and noncovalent interactions [43], and successfully used for kinetic calculations and reaction energies in antioxidant-free radical systems [44-46]. After the geometry optimizations, frequencies were calculated to obtain Gibbs free energies for each species and to confirm the nature of the stationary points. Minima had no imaginary frequencies, while TSs had exactly one. The values of these imaginary frequencies are given in Tables S1 and S2 . For each TS, the atom displacement associated to the imaginary frequency was coincident with the motion along the expected reaction coordinate. 
Solvent effects were included in all geometry optimizations by using the universal SMD implicit solvation model [47]. Two different solvents, water and pentyl ethanoate, were used to mimic an aqueous and a lipidic microenvironment, respectively. The cationic form of PM, which is the predominant one at physiological pH (7.4) [48], was modeled in water. This form has three different tautomers with a significant mole fraction at pH 7.4 [37] (Figure 1) and all three were used in the calculations. In pentyl ethanoate, only the completely neutral form was considered. Three reaction mechanisms were studied: (i) the transfer of each hydrogen atom from PM to the radical (hydrogen-atom transfer, HAT); (ii) the formation of an adduct between PM and the radical at each aromatic atom (radical-adduct formation, $\mathrm{RAF}$ ); and (iii) and the transfer of an electron (single-electron transfer, SET) from PM to the radical.

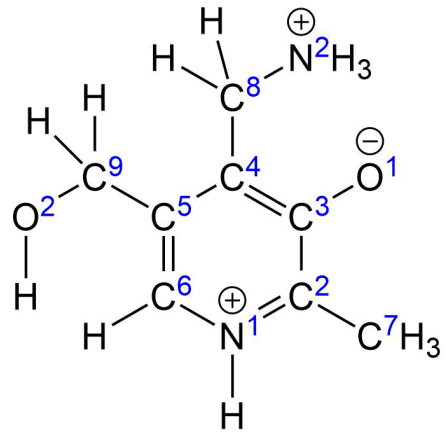

$\mathrm{H}_{2} \mathrm{PM}( \pm)$

$\chi=0.77$<smiles>[2H][13CH2]c1c([OH2+])c([CH2+])[nH+]c([2H])c1[C@H]([2H])O</smiles>

$\mathrm{H}_{2} \mathrm{PM}(0)$

$\chi=0.10$

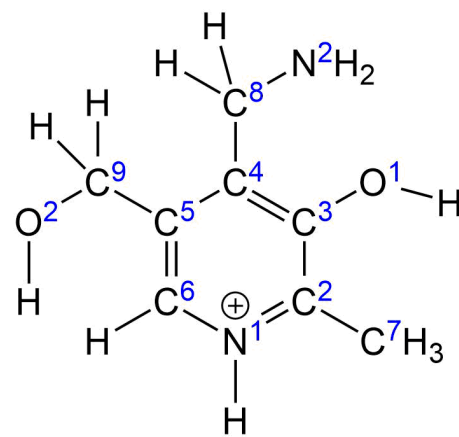

$\mathrm{H}_{2} \mathrm{PM}(+)$

$\chi=0.12$

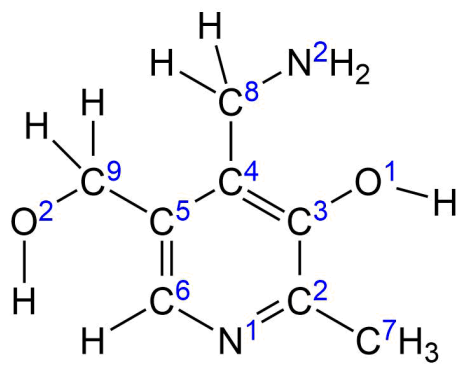

$\operatorname{HPM}(0)$

$\chi=1.00$

Figure 1. Atom numbering for the four pyridoxamine (PM) tautomers considered for calculations in water $\left(\mathrm{H}_{2} \mathrm{PM}( \pm), \mathrm{H}_{2} \mathrm{PM}(+)\right.$ and $\left.\mathrm{H}_{2} \mathrm{PM}(0)\right)$ and pentyl ethanoate $(\mathrm{HPM}(0))$. Mole fractions $\chi$ at physiological $\mathrm{pH}$ (7.4), calculated from the $\mathrm{pK}_{\mathrm{a}}$ values collected by Casasnovas et al. [37], are also indicated.

For each reaction, its standard reaction Gibbs free energy $\Delta G^{0}$ at $298.15 \mathrm{~K}$ was calculated as the difference between the Gibbs free energies of products and reactants, and only the reactions with a $\Delta G^{0}$ less than $1 \mathrm{kcal} / \mathrm{mol}$ were considered for the kinetic study. In these cases, activation Gibbs free energies $\Delta G^{\neq}$at $298.15 \mathrm{~K}$ were calculated as the differences between the Gibbs free energies of TSs and reactants. These $\Delta G^{\neq}$values are shown in Tables S3 and S4 . All $\Delta G^{0}$ and $\Delta G^{\neq}$values were referred to the standard state of $1 \mathrm{M}$. Solvent cage effects were considered by applying the corrections suggested by Okuno [49], based on the free volume theory [50].

Rate constants $k$ were calculated by applying conventional transition state theory (TST) by using Equation (1):

$$
k=\kappa \sigma \frac{k_{B} T}{h} e^{-\frac{\Delta G \neq}{R T}},
$$


where $k_{B}$ is the Boltzmann constant; $h$ is the Planck constant; $R$ is the ideal gas constant; $T$ is the absolute temperature; $\kappa$ is the tunneling correction; and $\sigma$ is the reaction path degeneracy, which takes into account the existence of different but equivalent reaction paths. Tunneling corrections $\kappa$ were applied when computing the rate constants for the HAT reactions by considering an Eckart barrier [51], as implemented in the program by Brown et al. [52]. Tables S1 and S2 display the values of $\kappa$ for all HAT reactions. For RAF reactions, no tunneling corrections were applied $(\kappa=1)$.

When rate constants $k$ were above the diffusion limit $\left(k>1.0 \times 10^{8} \mathrm{M}^{-1} \mathrm{~s}^{-1}\right)$, the Kimball-Collins theory [53] was used to correct them by applying Equation (2):

$$
k_{a p p}=\frac{k_{D} k}{k_{D}+k},
$$

where $k_{D}$ is the steady-state Smoluchowski rate constant for a diffusion-controlled, bimolecular, irreversible reaction, which is obtained from Equation (3) [54]:

$$
k_{D}=4 \pi R D_{A B} N_{A}
$$

where $R$ is the reaction distance; $N_{A}$ is the Avogadro number; and $D_{A B}$ is the mutual diffusion coefficient for the reactants $\mathrm{A}$ and $\mathrm{B}$, calculated as the sum of their diffusion coefficients $D_{A}$ and $D_{B}$, which are calculated with the Stokes-Einstein approach, given by Equation $(4)[55,56]$ :

$$
D_{i}=\frac{k_{B} T}{6 \pi \eta a_{i}}
$$

where $k_{B}$ is the Boltzmann constant; $T$ is the absolute temperature; $\eta$ is the solvent viscosity $\left(8.91 \times 10^{-4} \mathrm{~Pa} \cdot \mathrm{s}\right.$ for water and $8.62 \times 10^{-4} \mathrm{~Pa} \cdot \mathrm{s}$ for pentyl ethanoate); and $a_{i}$ is the radius of solute $i$, assuming it is spherical.

Overall rate constants for each combination of radical, solvent, mechanism and reaction site were calculated as the sums of the rate constants for each tautomer, weighted by their mole fractions $\chi_{i}$ at physiological $\mathrm{pH}$ (7.4), as shown in Equation (5):

$$
k_{\text {overall }}=\sum_{i=1}^{n} \chi_{i} k_{i},
$$

where $k_{i}$ is the rate constant for the $i$ th tautomer and $n$ is the number of tautomers ( 3 for water and 1 for pentyl ethanoate). Total rate constants $k_{\text {tot }}$ were computed for each combination of radical and solvent as the sum of the overall rate constants for all mechanisms and reaction sites, as shown in Equation (6):

$$
k_{\text {tot }}=\sum k_{\text {overall }}
$$

Branching ratios $\Gamma$ were also calculated for each combination of radical, solvent, mechanism and reaction site by using Equation (7):

$$
\Gamma=\frac{100 \cdot k_{\text {overall }}}{k_{\text {tot }}} .
$$

All geometry optimizations and frequency calculations were performed with the Gaussian 09 package, revision D.01 [57].

\section{Results}

The thermodynamics and kinetics of the different reaction pathways between $\mathrm{PM}$ and the $\bullet \mathrm{OOH}$, $\bullet \mathrm{OOCH}_{3}$ and $\bullet \mathrm{OCH}_{3}$ radicals were determined and analyzed in this study, both in a polar solvent (water) and in a nonpolar solvent (pentyl ethanoate). Three mechanisms were considered: 
- Hydrogen-atom transfer $(\mathrm{HAT}): \mathrm{PM}+\mathrm{R} \bullet \rightarrow \mathrm{PM}(-\mathrm{H}) \bullet+\mathrm{RH}$, considering each possible PM hydrogen atom.

- $\quad$ Radical-adduct formation (RAF): $\mathrm{PM}+\mathrm{R} \bullet \rightarrow[\mathrm{PM}-\mathrm{R}] \bullet$, at each aromatic PM atom.

- $\quad$ Single-electron transfer (SET): $\mathrm{PM}+\mathrm{R} \bullet \rightarrow \mathrm{PM}^{+} \bullet+\mathrm{R}^{-}$.

In water, the $\mathrm{H}_{2} \mathrm{PM}( \pm), \mathrm{H}_{2} \mathrm{PM}(+)$ and $\mathrm{H}_{2} \mathrm{PM}(0)$ tautomers of the monocationic form of $\mathrm{PM}$ were considered, whereas only the neutral form $\operatorname{HPM}(0)$ was modeled in pentyl ethanoate (Figure 1 ).

\subsection{Thermodynamic Study}

Thermodynamically, $\bullet \mathrm{OCH}_{3}$ is by far the most reactive of the three studied radicals in both solvents, and $\bullet \mathrm{OOH}$ is slightly more reactive than $\bullet \mathrm{OOCH}_{3}$ (Table 1). The standard reaction Gibbs free energies $\left(\Delta G^{0}\right)$ for all HAT reactions in water involving $\bullet \mathrm{OCH}_{3}$ are $18.5 \mathrm{kcal} / \mathrm{mol}$ lower than those with $\bullet \mathrm{OOH}$ at the same position, and $19.1 \mathrm{kcal} / \mathrm{mol}$ lower than those with $\bullet \mathrm{OOCH}_{3} . \Delta \mathrm{G}^{0}$ values for RAF reactions in water involving $\bullet \mathrm{OCH}_{3}$ are between 13.8 and $16.9 \mathrm{kcal} / \mathrm{mol}$ lower than the corresponding reactions involving $\bullet \mathrm{OOH}$ and between 15.7 and $19.7 \mathrm{kcal} / \mathrm{mol}$ lower than those with $\bullet \mathrm{OOCH}_{3}$. For SET reactions, the $\Delta G^{0}$ values for $\bullet \mathrm{OCH}_{3}$ are also lower than those for the other two radicals, although the differences are smaller: $5.5 \mathrm{kcal} / \mathrm{mol}$ in the case of $\bullet \mathrm{OOH}$ and $7.3 \mathrm{kcal} / \mathrm{mol}$ in the case of $\bullet \mathrm{OOCH}_{3}$.

Table 1. Standard reaction Gibbs free energies $\Delta G^{0}$ (in $\mathrm{kcal} / \mathrm{mol}$ ), at $298.15 \mathrm{~K}$ and 1 bar, for each combination of reaction site, pyridoxamine tautomer in water and free radical. See Figure 1 for nomenclature.

\begin{tabular}{cccccccccc}
\hline & \multicolumn{3}{c}{$\mathbf{H}_{\mathbf{2}} \mathbf{P M}( \pm \mathbf{)}$} & \multicolumn{3}{c}{$\mathbf{H}_{\mathbf{2}} \mathbf{P M ( + )}$} \\
\cline { 2 - 9 } & $\bullet \mathbf{O O H}$ & $\bullet \mathbf{O O C H}_{\mathbf{3}}$ & $\bullet \mathbf{O C H}_{\mathbf{3}}$ & $\bullet \mathbf{O O H}$ & $\bullet \mathbf{O O C H}_{\mathbf{3}}$ & $\bullet \boldsymbol{\bullet O C H}_{\mathbf{3}}$ & $\bullet \mathbf{O O H}$ & $\bullet \boldsymbol{O O O C H}_{\mathbf{3}}$ & $\bullet \mathbf{O C H}_{\mathbf{3}}$ \\
\hline HAT-C6 & 33.9 & 34.5 & 15.4 & 34.0 & 34.6 & 15.5 & 23.7 & 24.3 & 5.2 \\
HAT-C7 & -2.1 & -1.5 & -20.6 & 2.2 & 2.8 & -16.3 & 4.6 & 5.2 & -13.9 \\
HAT-C8 & -0.7 & -0.1 & -19.2 & -12.7 & -12.1 & -31.2 & 8.7 & 9.3 & -9.8 \\
HAT-C9 & -1.3 & -0.7 & -19.8 & -1.8 & -1.2 & -20.3 & 3.3 & 3.9 & -15.2 \\
HAT-N1 & -1.4 & -0.8 & -19.9 & 26.5 & 27.1 & 8.0 & - & - & - \\
HAT-N2 & 10.1 & 10.6 & -8.4 & 13.5 & 14.1 & -5.0 & 26.7 & 27.3 & 8.2 \\
HAT-O1 & - & - & - & 25.4 & 12.1 & -7.0 & 13.9 & 0.6 & -18.5 \\
HAT-O2 & 29.8 & 30.4 & 11.3 & 19.0 & 19.6 & 0.5 & 19.4 & 20.0 & 0.9 \\
\hline RAF-N1 & - & - & - & - & - & - & 42.7 & - & 27.6 \\
RAF-C2 & -5.3 & -2.9 & -20.5 & 11.4 & 15.3 & -4.3 & 12.8 & 16.2 & -1.0 \\
RAF-C3 & 20.7 & 22.2 & 4.1 & 17.9 & 19.5 & 2.0 & 15.2 & 17.3 & 0.2 \\
RAF-C4 & 0.9 & 2.8 & -15.4 & 13.3 & 16.8 & -2.9 & 17.6 & 20.3 & 0.7 \\
RAF-C5 & 19.9 & 21.5 & 4.1 & 19.6 & 19.8 & 3.1 & 16.2 & 18.2 & 1.8 \\
RAF-C6 & -2.5 & 0.4 & -17.4 & 11.8 & 13.1 & -2.6 & 10.5 & 13.6 & -3.7 \\
\hline SET & 26.3 & 28.1 & 20.8 & 62.0 & 63.8 & 56.5 & 41.5 & 43.3 & 36.0 \\
\hline
\end{tabular}

HAT: Hydrogen-atom transfer. RAF: Radical-adduct formation. SET: Single-electron transfer. The letter and number next to each abbreviation indicate the reaction site, as defined in Figure 1.

In pentyl ethanoate, the trends are the same (Table 2). $\Delta G^{0}$ values for HAT reactions with $\bullet \mathrm{OCH}_{3}$ are $18.3 \mathrm{kcal} / \mathrm{mol}$ lower than those involving $\bullet \mathrm{OOH}$ and $19.8 \mathrm{kcal} / \mathrm{mol}$ lower than those with $\bullet \mathrm{OOCH}_{3}$. For RAF reactions, the differences are between 12.9 and $15.6 \mathrm{kcal} / \mathrm{mol}$ for $\bullet \mathrm{OOH}$ and between 16.8 and $19.3 \mathrm{kcal} / \mathrm{mol}$ for $\bullet \mathrm{OOCH}_{3}$. The $\Delta G^{0}$ for the SET reaction involving $\bullet \mathrm{OCH}_{3}$ in pentyl ethanoate is $8.1 \mathrm{kcal} / \mathrm{mol}$ lower than that for $\bullet \mathrm{OOH}$ and $9.4 \mathrm{kcal} / \mathrm{mol}$ lower than that for $\bullet \mathrm{OOCH}_{3}$. 
Table 2. Standard reaction Gibbs free energies $\Delta G^{0}$ (in $\mathrm{kcal} / \mathrm{mol}$ ), at $298.15 \mathrm{~K}$ and 1 bar, for each combination of reaction site and free radical in pentyl ethanoate. See Figure 1 for nomenclature.

\begin{tabular}{cccc}
\hline & \multicolumn{3}{c}{ HPM(0) } \\
\cline { 2 - 4 } & $\bullet$ OOH & $\bullet \mathbf{O O C H}_{3}$ & $\bullet \boldsymbol{O C H}_{3}$ \\
\hline HAT-C6 & 23.1 & 24.6 & 4.8 \\
HAT-C7 & 5.6 & 7.0 & -12.8 \\
HAT-C8 & -0.2 & 1.2 & -18.5 \\
HAT-C9 & 0.3 & 1.7 & -18.0 \\
HAT-N2 & 19.2 & 20.6 & 0.9 \\
HAT-O1 & 6.9 & 8.3 & -11.4 \\
HAT-O2 & 19.7 & 21.1 & 1.3 \\
\hline RAF-N1 & 42.6 & - & 29.3 \\
RAF-C2 & 11.1 & 15.0 & -1.8 \\
RAF-C3 & 14.8 & 19.3 & 0.0 \\
RAF-C4 & 13.8 & 17.2 & -1.8 \\
RAF-C5 & 16.1 & 18.8 & 1.1 \\
RAF-C6 & 10.7 & 15.6 & -3.6 \\
\hline SET & 89.4 & 90.7 & 81.3 \\
\hline
\end{tabular}

HAT: Hydrogen-atom transfer. RAF: Radical-adduct formation. SET: Single-electron transfer. The letter and number next to each abbreviation indicate the reaction site, as defined in Figure 1.

The most exergonic reaction pathway for the scavenging of $\bullet \mathrm{OCH}_{3}$ in water is the abstraction of the $\mathrm{C} 8$ hydrogen atom of the $\mathrm{H}_{2} \mathrm{PM}(+)$ tautomer $\left(\Delta G^{0}=-31.2 \mathrm{kcal} / \mathrm{mol}\right)$. In general, the HAT reactions at the $\mathrm{C} 7, \mathrm{C} 8$ and $\mathrm{C} 9$ of all three tautomers in water are highly exergonic pathways for the scavenging of this radical. In addition, hydrogen abstractions from the $\mathrm{N} 1$ and $\mathrm{N} 2 \mathrm{of}_{2} \mathrm{PM}( \pm)$ and from the $\mathrm{O} 1$ of $\mathrm{H}_{2} \mathrm{PM}(0)$, as well as the RAF reactions at the $\mathrm{C} 2, \mathrm{C} 4$ and $\mathrm{C} 6 \mathrm{of}_{2} \mathrm{PM}( \pm)$, are thermodynamically favored pathways for the scavenging of $\bullet \mathrm{OCH}_{3}$. There are other pathways that could also be thermodynamically possible, although with smaller negative (or even slightly positive) $\Delta G^{0}$ values: the HAT reactions at $\mathrm{N} 2, \mathrm{O} 1$ and $\mathrm{O} 2$ and the radical additions at $\mathrm{C} 2, \mathrm{C} 4$ and $\mathrm{C} 6$ of $\mathrm{H}_{2} \mathrm{PM}(+)$; and the HAT reaction at $\mathrm{O} 2$ and the radical additions at $\mathrm{C} 2, \mathrm{C} 3, \mathrm{C} 4$ and $\mathrm{C} 6$ of $\mathrm{H}_{2} \mathrm{PM}(0)$. In pentyl ethanoate, the trends do not vary much. The thermodynamically most favored mechanism to scavenge $\bullet \mathrm{OCH}_{3}$ is the HAT reaction at $\mathrm{C} 8\left(\Delta G^{0}=-18.5 \mathrm{kcal} / \mathrm{mol}\right)$, followed by the HAT reactions at $\mathrm{C} 9, \mathrm{C} 7$ and $\mathrm{O} 1$. The RAF reactions at $\mathrm{C} 2, \mathrm{C} 3, \mathrm{C} 4$ and $\mathrm{C} 6$, and the HAT reaction at $\mathrm{N} 2$ could be feasible as well, since their $\Delta G^{0}$ values are either slightly negative or slightly positive. All other pathways, such as the hydrogen abstractions from the $\mathrm{sp}^{2}$ carbon (C6) and especially the SET reactions, are clearly endergonic.

The most negative $\Delta G^{0}$ values for the scavenging of both $\bullet \mathrm{OOH}$ and $\bullet \mathrm{OOCH}_{3}$ in water also correspond to the abstraction of a hydrogen atom from the $\mathrm{C} 8 \mathrm{of}_{2} \mathrm{PM}(+)$ (i.e., -12.7 and $-12.1 \mathrm{kcal} / \mathrm{mol}$, respectively). In pentyl ethanoate, the most favorable pathways for these two radicals are the same as in water, although with $\Delta G^{0}$ values close to $0(-0.2$ and $1.2 \mathrm{kcal} / \mathrm{mol}$, respectively). All the other pathways either have $\Delta G^{0}$ values around 0 (i.e., hydrogen abstractions from the $C 7$, $\mathrm{C} 8, \mathrm{C} 9$ and $\mathrm{N} 1$ atoms and radical additions to the $\mathrm{C} 2, \mathrm{C} 4$ and $\mathrm{C} 6$ atoms of $\mathrm{H}_{2} \mathrm{PM}( \pm)$; hydrogen abstraction from the $\mathrm{C} 9$ of $\mathrm{H}_{2} \mathrm{PM}(+)$ and, in the case of $\bullet \mathrm{OOCH}_{3}$, from the $\mathrm{O} 1 \mathrm{of}_{2} \mathrm{PM}(0)$ ), or are clearly endergonic (e.g., hydrogen abstractions from the aromatic $\mathrm{C} 6$ atom and SET reactions).

In most cases, the radical adducts at $\mathrm{N} 1$ are not stable (their optimization results in their dissociation). In the few cases in which they do not dissociate, their formation is largely endergonic $\left(\Delta G^{0}\right.$ values between 27.6 and $\left.42.7 \mathrm{kcal} / \mathrm{mol}\right)$.

All pathways characterized as clearly endergonic $\left(\Delta G^{0}>1 \mathrm{kcal} / \mathrm{mol}\right)$ were discarded as possible mechanisms to explain the ability of PM to scavenge ROS because, even if they took place at a significant rate, they would be reversible. Nevertheless, they would represent possible pathways if their products further reacted, in subsequent steps, with small activation barriers and high exergonicity. 


\subsection{Kinetic Study}

Those reaction mechanisms with $\Delta G^{0}$ values below $1 \mathrm{kcal} / \mathrm{mol}$ were further analyzed from a kinetic point of view. The $\bullet \mathrm{OCH}_{3}$ radical is the one exhibiting the highest rate constants. The $\mathrm{H}_{2} \mathrm{PM}( \pm)$ tautomer, which is predominant at physiological $\mathrm{pH}$, is also the most reactive. It seems that $\bullet \mathrm{OCH}_{3}$ may react with rate constants higher than the diffusion limit $\left(>1.0 \times 10^{8} \mathrm{M}^{-1} \mathrm{~s}^{-1}\right)$ by several mechanisms (Tables 3 and 4): (i) via a HAT reaction at the $\mathrm{N} 1$ and $\mathrm{N} 2$ sites of the $\mathrm{H}_{2} \mathrm{PM}( \pm$ ) tautomer and at the phenolic oxygen (O1) of the $\mathrm{H}_{2} \mathrm{PM}(+), \mathrm{H}_{2} \mathrm{PM}(0)$ and $\mathrm{HPM}(0)$ tautomers; or (ii) through a RAF reaction at the $\mathrm{C} 6$ site of the $\mathrm{H}_{2} \mathrm{PM}( \pm)$ tautomer. For the mentioned HAT reactions involving the $\bullet \mathrm{OCH}_{3}$ radical, no TS could be located at the level of theory used. However, a relaxed scan of the X-H distances (where $\mathrm{X}$ is $\mathrm{N} 1, \mathrm{~N} 2$ or O1), leading from reactants to products, revealed a monotonic decrease of the energy (with no maximum along the way), suggesting that these reactions are strictly diffusion-controlled (i.e., every encounter between the reactants would yield the products). In contrast, we could find the TS corresponding to the diffusion-controlled $\bullet \mathrm{OCH}_{3}$ RAF reaction at the $\mathrm{C} 6$ atom of $\mathrm{H}_{2} \mathrm{PM}( \pm)$ (Figure 2). The structures and the Cartesian coordinates of all TSs found in this study are given in the Supplementary Materials. Other pathways with high rate constants for the scavenging of $\bullet \mathrm{OCH}_{3}$ are the formation of a radical adduct at the $\mathrm{C} 2$ and $\mathrm{C} 4$ positions of $\mathrm{H}_{2} \mathrm{PM}( \pm)$ (in the order of $10^{7}$ and $10^{6} \mathrm{M}^{-1} \mathrm{~s}^{-1}$, respectively). Moderate rate constants are found for $\bullet \mathrm{OCH}_{3} \mathrm{HAT}$ reactions at the aliphatic carbon atoms (C7, C8 and C9) of all four tautomers (in the order of $10^{3}-10^{6} \mathrm{M}^{-1} \mathrm{~s}^{-1}$ ).

Table 3. Rate constants $k$ (in $\mathrm{M}^{-1} \mathrm{~s}^{-1}$ ), at $298.15 \mathrm{~K}$ and 1 bar, for those combinations of reaction site, pyridoxamine tautomer and free radical where the standard reaction Gibbs free energy is less than $1 \mathrm{kcal} / \mathrm{mol}$. See Figure 1 for nomenclature.

\begin{tabular}{lccccccccc}
\hline & \multicolumn{3}{c}{$\mathbf{H}_{\mathbf{2}} \mathbf{P M}( \pm$ ) } & & $\mathbf{H}_{\mathbf{2}} \mathbf{P M}(+)$ & & $\mathbf{H}_{\mathbf{2}} \mathbf{P M}(\mathbf{0})$ & \multicolumn{2}{c}{$\mathbf{H P M ( 0 )}$} \\
\cline { 2 - 9 } & $\bullet \mathbf{O O H}$ & $\bullet \mathbf{O O C H}_{3}$ & $\bullet \mathbf{O C H}_{3}$ & $\bullet \mathbf{O O H}$ & $\bullet \mathbf{O O C H}_{3}$ & $\bullet \mathbf{O C H}_{3}$ & $\bullet \mathbf{O C H}_{3}$ & $\bullet \mathbf{O O H}$ & $\bullet \mathbf{O C H}_{3}$ \\
\hline HAT-C7 & $2.8 \times 10^{1}$ & $2.8 \times 10^{0}$ & $3.3 \times 10^{5}$ & - & - & $1.4 \times 10^{5}$ & $1.0 \times 10^{5}$ & - & $2.0 \times 10^{4}$ \\
HAT-C8 & $1.1 \times 10^{0}$ & $1.1 \times 10^{-1}$ & $4.2 \times 10^{4}$ & $1.8 \times 10^{0}$ & $2.7 \times 10^{0}$ & $9.6 \times 10^{4}$ & $4.2 \times 10^{3}$ & $4.0 \times 10^{1}$ & $1.7 \times 10^{6}$ \\
HAT-C9 & $6.8 \times 10^{-1}$ & $2.8 \times 10^{-1}$ & $7.0 \times 10^{5}$ & $2.9 \times 10^{0}$ & $1.8 \times 10^{-1}$ & $3.1 \times 10^{5}$ & $1.8 \times 10^{5}$ & $1.1 \times 10^{0}$ & $7.3 \times 10^{4}$ \\
HAT-N1 & - & - & $2.9 \times 10^{9}$ & - & - & - & - & - & - \\
HAT-N2 & - & - & $2.8 \times 10^{9}$ & - & - & $5.6 \times 10^{1}$ & - & - & $1.7 \times 10^{2}$ \\
HAT-O1 & - & - & - & - & - & $3.0 \times 10^{9}$ & $2.9 \times 10^{9}$ & - & $3.0 \times 10^{9}$ \\
HAT-O2 & - & - & - & - & - & $2.8 \times 10^{-1}$ & $5.6 \times 10^{-2}$ & - & - \\
\hline RAF-C2 & $3.1 \times 10^{4}$ & $1.1 \times 10^{4}$ & $9.1 \times 10^{7}$ & - & - & $6.1 \times 10^{-1}$ & $3.9 \times 10^{0}$ & - & $1.1 \times 10^{2}$ \\
RAF-C3 & - & - & - & - & - & - & $1.2 \times 10^{1}$ & - & $3.5 \times 10^{3}$ \\
RAF-C4 & $1.1 \times 10^{2}$ & - & $6.4 \times 10^{6}$ & - & - & $3.8 \times 10^{4}$ & $1.6 \times 10^{0}$ & - & $9.5 \times 10^{3}$ \\
RAF-C6 & $9.9 \times 10^{3}$ & $2.1 \times 10^{2}$ & $2.1 \times 10^{8}$ & - & - & $1.8 \times 10^{0}$ & $2.8 \times 10^{3}$ & - & $1.5 \times 10^{4}$ \\
\hline
\end{tabular}

HAT: Hydrogen-atom transfer. RAF: Radical-adduct formation. The letter and number next to each abbreviation indicate the reaction site, as defined in Figure 1.

Table 4. Overall rate constants $k_{\text {overall }}$ (in $\mathrm{M}^{-1} \mathrm{~s}^{-1}$ ) and branching ratios, at $298.15 \mathrm{~K}$ and 1 bar, and at physiological $\mathrm{pH}$ (7.4), for each free radical in each solvent at each reaction site. Total rate constants $k_{\text {tot }}\left(\right.$ in $\mathrm{M}^{-1} \mathrm{~s}^{-1}$ ), calculated as the sum of all $k_{\text {overall }}$ for each radical in each solvent, are also indicated. See Figure 1 for nomenclature.

\begin{tabular}{lccccc}
\hline & \multicolumn{3}{c}{ Water } & \multicolumn{2}{c}{ Pentyl Ethanoate } \\
\cline { 2 - 6 } & $\bullet$ OOH & $\bullet \mathbf{O O C H}_{3}$ & $\bullet \mathbf{O C H}_{3}$ & $\bullet \mathbf{O O H}$ & $\bullet \mathbf{O C H}_{3}$ \\
\hline HAT-C7 & $2.1 \times 10^{1}(<0.1 \%)$ & $2.1 \times 10^{0}(<0.1 \%)$ & $2.8 \times 10^{5}(<0.1 \%)$ & $\approx 0$ & $2.0 \times 10^{4}(<0.1 \%)$ \\
HAT-C8 & $1.1 \times 10^{0}(<0.1 \%)$ & $4.1 \times 10^{-1}(<0.1 \%)$ & $4.4 \times 10^{4}(<0.1 \%)$ & $4.0 \times 10^{1}(97.3 \%)$ & $1.7 \times 10^{6}(<0.1 \%)$ \\
HAT-C9 & $8.7 \times 10^{-1}(<0.1 \%)$ & $2.4 \times 10^{-1}(<0.1 \%)$ & $6.0 \times 10^{5}(<0.1 \%)$ & $1.1 \times 10^{0}(2.7 \%)$ & $7.3 \times 10^{4}(<0.1 \%)$ \\
HAT-N1 & $\approx 0$ & $\approx 0$ & $2.2 \times 10^{9}(42.0 \%)$ & - & - \\
HAT-N2 & $\approx 0$ & $\approx 0$ & $2.2 \times 10^{9}(41.2 \%)$ & $\approx 0$ & $1.7 \times 10^{2}(<0.1 \%)$ \\
HAT-O1 & $\approx 0$ & $\approx 0$ & $6.6 \times 10^{8}(12.4 \%)$ & $\approx 0$ & $3.0 \times 10^{9}(99.9 \%)$ \\
HAT-O2 & $\approx 0$ & $\approx 0$ & $3.9 \times 10^{-2}(<0.1 \%)$ & $\approx 0$ & $\approx 0$ \\
\hline
\end{tabular}


Table 4. Cont.

\begin{tabular}{cccccc}
\hline & \multicolumn{3}{c}{ Water } & \multicolumn{2}{c}{ Pentyl Ethanoate } \\
\cline { 2 - 6 } & $\bullet \mathbf{O O H}$ & $\bullet \mathbf{O O C H}_{3}$ & $\bullet \mathbf{O C H}_{\mathbf{3}}$ & $\bullet \mathbf{O O H}$ & $\bullet \mathbf{O C H}_{3}$ \\
\hline RAF-C2 & $2.4 \times 10^{4}(75.6 \%)$ & $8.1 \times 10^{3}(98.0 \%)$ & $6.9 \times 10^{7}(1.3 \%)$ & $\approx 0$ & $1.1 \times 10^{2}(<0.1 \%)$ \\
RAF-C3 & $\approx 0$ & $\approx 0$ & $1.2 \times 10^{0}(<0.1 \%)$ & $\approx 0$ & $3.5 \times 10^{3}(<0.1 \%)$ \\
RAF-C4 & $8.6 \times 10^{1}(0.3 \%)$ & $\approx 0$ & $4.9 \times 10^{6}(0.1 \%)$ & $\approx 0$ & $9.5 \times 10^{3}(<0.1 \%)$ \\
RAF-C6 & $7.6 \times 10^{3}(24.0 \%)$ & $1.6 \times 10^{2}(1.9 \%)$ & $1.6 \times 10^{8}(3.1 \%)$ & $\approx 0$ & $1.5 \times 10^{4}(<0.1 \%)$ \\
\hline $\boldsymbol{k}_{\text {tot }}$ & $3.2 \times 10^{4}$ & $8.3 \times 10^{3}$ & $5.3 \times 10^{9}$ & $4.2 \times 10^{1}$ & $3.0 \times 10^{9}$ \\
\hline
\end{tabular}

HAT: Hydrogen-atom transfer. RAF: Radical-adduct formation. The letter and number next to each abbreviation indicate the reaction site, as defined in Figure 1.

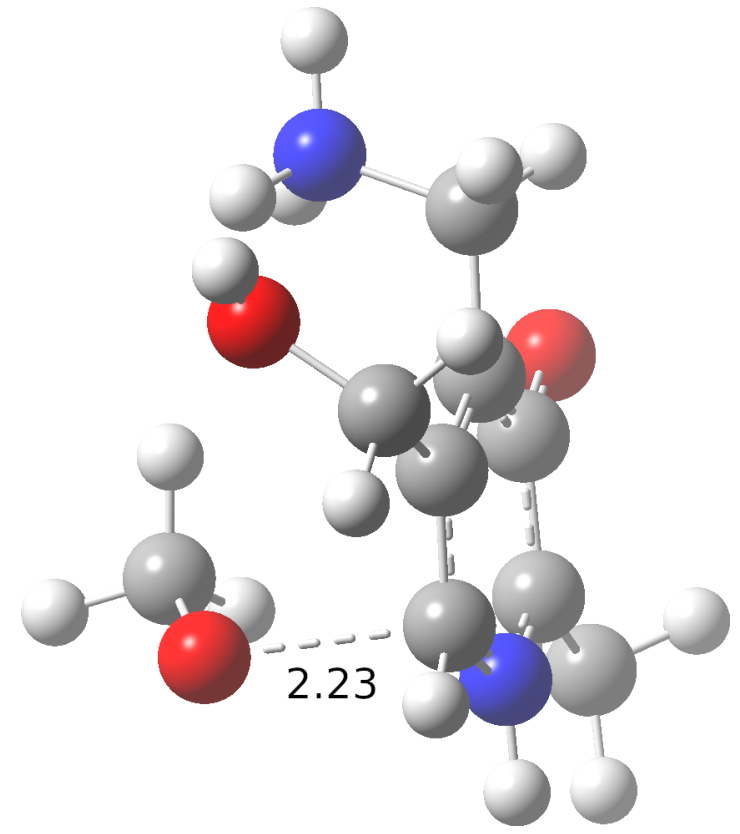

Figure 2. Transition state for the RAF reaction between the $\mathrm{H}_{2} \mathrm{PM}( \pm)$ tautomer of pyridoxamine and the $\bullet \mathrm{OCH}_{3}$ radical at $\mathrm{C} 6$, which is the fastest reaction for which a transition state was located. The distance between the oxygen atom of $\bullet \mathrm{OCH}_{3}$ and the $\mathrm{C} 6$ atom of $\mathrm{H}_{2} \mathrm{PM}( \pm)$ is given in $\AA$.

The other two radicals are not particularly reactive at any position, with only moderate rate constants for the RAF reactions at the $\mathrm{C} 2$ and $\mathrm{C} 6$ atoms of $\mathrm{H}_{2} \mathrm{PM}( \pm)$ (in the order of $10^{4}$ and $10^{3} \mathrm{M}^{-1} \mathrm{~s}^{-1}$, respectively, for $\bullet \mathrm{OOH}$; and in the order of $10^{4}$ and $10^{2} \mathrm{M}^{-1} \mathrm{~s}^{-1}$, respectively, for $\bullet \mathrm{OOCH}_{3}$ ) and at its $\mathrm{C} 4$ atom (in the order of $10^{2} \mathrm{M}^{-1} \mathrm{~s}^{-1}$ for $\bullet \mathrm{OOH}$ ). The rate constants at the remaining thermochemically viable sites are negligible $\left(<10^{2} \mathrm{M}^{-1} \mathrm{~s}^{-1}\right)$. For the HAT reactions at the $\mathrm{N} 1$ atom of $\mathrm{H}_{2} \mathrm{PM}( \pm)$ involving $\bullet \mathrm{OOH}$ and $\bullet \mathrm{OOCH}_{3}$, and for the HAT reaction at the $\mathrm{O} 1$ atom of $\mathrm{H}_{2} \mathrm{PM}(0)$ involving $\bullet \mathrm{OOCH}_{3}$, again no TSs could located at the level of theory used. However, as opposed to the case of $\bullet \mathrm{OCH}_{3}$, a relaxed scan of the X-H distances (where X is N1 or O1) resulted in a monotonic increase of the energy (with no maximum along the way) when moving from reactants to products, suggesting that, in these cases, the inverse HAT reactions (i.e., the transfer of hydrogen from the radicals to PM) are the ones that are strictly diffusion-controlled. Therefore, these reactions were also discarded as viable pathways for the scavenging of these radicals.

PM would be able to scavenge the $\bullet \mathrm{OCH}_{3}$ radical in an aqueous environment with a total rate constant $\left(k_{t o t}\right)$ of $5.3 \times 10^{9} \mathrm{M}^{-1} \mathrm{~s}^{-1}$ (Table 4$)$, with HAT reactions at both nitrogen atoms N1 and $\mathrm{N} 2$ and at the phenolic oxygen $\mathrm{O} 1$ as the preferred reaction pathways (branching ratios of $42.0 \%, 41.2 \%$ and $12.4 \%$, respectively). In a lipidic medium, the scavenging of $\bullet \mathrm{OCH}_{3}$ would also be diffusion-controlled, with a $k_{\text {tot }}$ value of $3.0 \times 10^{9} \mathrm{M}^{-1} \mathrm{~s}^{-1}$, being the HAT reaction at the phenolic oxygen the unique non-negligible pathway. The other two radicals would be moderately scavenged in 
an aqueous environment, with $k_{\text {tot }}$ values of $3.2 \times 10^{4}$ and $8.3 \times 10^{3} \mathrm{M}^{-1} \mathrm{~s}^{-1}$ for $\bullet \mathrm{OOH}$ and $\bullet \mathrm{OOCH}_{3}$, respectively. In the case of $\bullet \mathrm{OOH}$, the scavenging would take place mainly through the formation of radical adducts at the $\mathrm{C} 2$ and $\mathrm{C} 6$ atoms (branching ratios of $75.6 \%$ and $24.0 \%$, respectively), and in the case of $\bullet \mathrm{OOCH}_{3}$, the single preferred pathway would be the formation of a radical adduct at $\mathrm{C} 2$ (with a branching ratio of $98.0 \%$ ). In a lipidic environment, however, PM would not efficiently scavenge $\bullet \mathrm{OOH}$ or $\bullet \mathrm{OOCH}_{3}\left(k_{\text {tot }}\right.$ values below $10^{2} \mathrm{M}^{-1} \mathrm{~s}^{-1}$; for $\bullet \mathrm{OOCH}_{3}$, none of the studied pathways would be thermochemically feasible).

\subsection{Comparison to Other Studies}

Matxain et al. reported a DFT study on the reactivity of $\mathrm{PN}$ with $\bullet \mathrm{OH}, \bullet \mathrm{OOH}$ and $\bullet \mathrm{O}_{2}{ }^{-}$[28]. The study concluded, from thermodynamical considerations, that $\bullet \mathrm{OH}$ would preferentially abstract a hydrogen atom from any of the methylene moieties or from the phenol group $\left(\Delta G^{0}\right.$ between -33 and $-39 \mathrm{kcal} / \mathrm{mol}$ ), while it could also form adducts at the aromatic $C$ atoms adjacent to the pyridine nitrogen (i.e., $\mathrm{C} 2$ and $\mathrm{C} 6)\left(\Delta G^{0}\right.$ around $\left.-6 \mathrm{kcal} / \mathrm{mol}\right)$. On the other hand, $\bullet \mathrm{OOH}$ would only react at the same two aromatic $\mathrm{C}$ atoms $\left(\Delta G^{0}\right.$ around $\left.-7 \mathrm{kcal} / \mathrm{mol}\right)$ and $\bullet \mathrm{O}_{2}{ }^{-}$would not react at all. Despite focusing on a different vitamin $\mathrm{B}_{6}$ vitamer and using a different DFT functional (B3LYP), these results are in qualitative agreement with our kinetic study, which shows that, in the case of $\mathrm{PM}$, the phenol hydrogen abstraction is among the preferred routes for the more reactive $\bullet \mathrm{OCH}_{3}$ radical $\left(k_{\text {overall }} \approx 10^{9} \mathrm{M}^{-1} \mathrm{~s}^{-1}\right)$ with hydrogen abstractions from the methylene groups (C8 and C9) being also highly favorable $\left(k_{\text {overall }} \approx 10^{4}-10^{6} \mathrm{M}^{-1} \mathrm{~s}^{-1}\right)$, while the less reactive $\bullet \mathrm{OOH}$ and $\bullet \mathrm{OOCH}_{3}$ radicals would be preferentially scavenged via additions at $\mathrm{C} 2$ and/or $\mathrm{C} 6\left(k_{\text {overall }} \approx 10^{2}-10^{4} \mathrm{M}^{-1} \mathrm{~s}^{-1}\right)$. The difference is that, unlike the PN model used in the study by Matxain et al., PM displays additional tautomers containing a protonated pyridine nitrogen or a protonated amino group that also represent preferred HAT reaction sites.

The differences in thermodynamics and kinetics among the three studied radicals are in line with their different stabilities: peroxyl radicals $\mathrm{ROO} \bullet$ are much more stable than corresponding alkoxyl radicals $\mathrm{RO} \bullet$ due to electron donation from the adjacent oxygen lone pairs to the half-empty orbital on the terminal oxygen (hence, $\bullet \mathrm{OOCH}_{3}$ is much more stable than $\bullet \mathrm{OCH}_{3}$ ), and the methyl group in $\bullet \mathrm{OOCH}_{3}$ also makes it slightly more stable than $\bullet \mathrm{OOH}$ due to electron density donation. The more stable a radical is, the less reactivity it will show, hence $\bullet \mathrm{OOCH}_{3}$ is much less reactive than $\bullet \mathrm{OCH}_{3}$ and slightly less reactive than $\bullet \mathrm{OOH}$. Identical reactivity trends are obtained in many similar DFT studies of antioxidant-free radical reactions [31,32,58], including a recent investigation on the thermodynamics of HAT reactions between cinnamic acid derivatives and ten oxygen-centered radicals of different nature, in both water and pentyl ethanoate [59].

Considering that $\bullet \mathrm{OOH}$ and $\bullet \mathrm{OOCH}_{3}$ are less reactive than other free radicals, overall rate constants in water in the order of $10^{4}$ and $10^{3} \mathrm{M}^{-1} \mathrm{~s}^{-1}$, respectively, for their reactions with PM indicate a notorious radical scavenging ability. The overall rate constant for $\bullet \mathrm{OOH}$ is similar to that of antioxidants such as capsaicin $\left(2.07 \times 10^{4} \mathrm{M}^{-1} \mathrm{~s}^{-1}\right)$ [58] or $\beta$-carotene $\left(5.69 \times 10^{4} \mathrm{M}^{-1} \mathrm{~s}^{-1}\right)$ [60] and better than that of allicin $\left(8 \times 10^{3} \mathrm{M}^{-1} \mathrm{~s}^{-1}\right)$ [61] or melatonin $\left(2 \times 10^{1} \mathrm{M}^{-1} \mathrm{~s}^{-1}\right)$ [34]. However, it does not perform as well as $\alpha$-tocopherol $\left(1.5 \times 10^{5}-7.9 \times 10^{6} \mathrm{M}^{-1} \mathrm{~s}^{-1}\right)$ [62], canolol $\left(2.47 \times 10^{6} \mathrm{M}^{-1} \mathrm{~s}^{-1}\right)$ [33], most guaiacol derivatives $\left(1.54 \times 10^{5}-1.65 \times 10^{7} \mathrm{M}^{-1} \mathrm{~s}^{-1}\right)$ [63] or sesamol $\left(2.44 \times 10^{8} \mathrm{M}^{-1} \mathrm{~s}^{-1}\right)$ [64].

\section{Discussion}

Although the active form of vitamin $\mathrm{B}_{6}$ in our bodies is pyridoxal $5^{\prime}$-phosphate (PLP) and in food it is mainly present as PN, PM has been regarded as the vitamin $\mathrm{B}_{6}$ vitamer with the highest ability to inhibit post-Amadori reactions and, consequently, the formation of AGEs [23,65]. For this reason, the present study focuses specifically on this form of vitamin $B_{6}$ to shed new light on one of the possible mechanisms underlying this inhibitory activity. The other two forms have also been reported to show antioxidant activity $[66,67]$ and the aforementioned study on the ROS trapping ability of PN [28] shows that it shares some of the preferred reaction sites with PM (namely, the phenol group, 
the methylene moieties and the aromatic carbons adjacent to the pyridine nitrogen). Since PLP also displays all these structural elements, it is plausible that it also scavenges ROS by similar mechanisms.

PM has been proven to act therapeutically on diabetic rats and humans displaying renal, retinal or cardiovascular dysfunctions [12-15]. Several attempts to elucidate its mechanism of action have pointed PM as a potent inhibitor of post-Amadori reactions, both in vitro and in vivo [23]. Over the past decade, our group has studied the reactivity of PM towards several carbohydrates and other carbonyls with a notorious glycation potential. Our results revealed that PM can form Schiff bases with rate constants one order of magnitude higher than those for the same reactions occurred on amino acids [19,38]. These results suggest that PM is also an effective inhibitor of the first stages of the protein glycation process.

Our group has also conducted studies on the ability of PM to trap different model Amadori compounds and to chelate different metal cations which catalyze their autoxidation [16]. These studies concluded that the key to explain the inhibitory activity of PM is its strong metal chelation ability and not its interaction with Amadori intermediates, in agreement with a previous work by Voziyan and colleagues [68]. This conclusion was further supported by two DFT studies showing that PM could compete against a model Amadori compound to chelate $\mathrm{Cu}^{2+}$ and $\mathrm{Fe}^{3+}$, while aminoguanidine could not, thereby explaining the fact that aminoguanidine cannot prevent the oxidation of Amadori compounds despite its ability to chelate metal ions [35,36]. Although PM does not interact directly with the carbonyl group of Amadori compounds, it can inhibit its degradation to many small RCS such as glyoxal, methylglyoxal and glycolaldehyde [20,69,70].

In the 2000s, several works additionally suggested a potent antioxidant activity of vitamin $\mathrm{B}_{6}$, comparable to that of $\alpha$-tocopherol or ascorbic acid [71-75]. In fact, PM is able to scavenge the ABTS $^{+} \bullet$ radical cation used in the TEAC assay, although relatively slowly [76]. Subsequent theoretical studies carried out by Matxain and coworkers showed that $\mathrm{PN}$, another form of vitamin $\mathrm{B}_{6}$, is highly reactive towards singlet oxygen [77] and hydroxyl radicals [28,29] but not against superoxide [28]. The transfer of the phenolic hydrogen atom could contribute significantly to this antioxidant activity [78], in perfect agreement with our findings. Furthermore, a recent study showing that PM reduces the levels of intracellular ROS induced by the glycation of the human serum albumin protein, further supports the idea that PM is a powerful antioxidant [79].

The study reported herein strengthens the hypothesis that PM can inhibit protein glycation and the cellular damage induced by its side reactions through the efficient scavenging of ROS. We have proved that PM would efficiently trap reactive radical species such as $\bullet \mathrm{OCH}_{3}$ and, in an aqueous environment, it would be moderately reactive towards peroxyl $(\bullet \mathrm{OOH})$ or alkyl peroxyl radicals such as $\bullet \mathrm{OOCH}_{3}$. This ability of PM to trap ROS would complement its activity as a metal chelator and as a small RCS scavenger in the context of post-Amadori inhibition of AGEs formation.

Two limitations of this study should be pointed out. The first one is that only the monocationic tautomers of PM have been modeled in water, since more than $99 \%$ of PM exists in this form at physiological $\mathrm{pH}$. However, if any of the dicationic, neutral or monoanionic tautomers were reactive enough, this fact would compensate its low mole fraction and it would have a non-negligible role in ROS scavenging. The second one is that only the three most common mechanisms (HAT, RAF and SET) for antioxidant-free radical reactions have been considered, but alternative mechanisms might also contribute. In any case, in either of these two scenarios the conclusion that PM is a potent ROS scavenger would still hold. An interesting follow-up of this study would be the modeling of ROS scavenging by PLP, with the same methodology used herein, to compare the results with PM and find out whether it could act in a similar way in the context of AGE formation inhibition.

\section{Conclusions}

In this study, the primary antioxidant activity of PM, one of the natural forms of vitamin $\mathrm{B}_{6}$, together with PN and PL, was investigated by performing DFT calculations at the M05-2X/6-311+G(d,p)/SMD level of theory. The results show that PM is an effective scavenger of the $\bullet \mathrm{OCH}_{3}$ radical, in both aqueous 
$\left(k_{t o t}=5.3 \times 10^{9} \mathrm{M}^{-1} \mathrm{~s}^{-1}\right)$ and lipidic $\left(k_{t o t}=3.0 \times 10^{9} \mathrm{M}^{-1} \mathrm{~s}^{-1}\right)$ microenvironments, and a moderate scavenger of $\bullet \mathrm{OOH}$ and $\bullet \mathrm{OOCH}_{3}$ in aqueous media $\left(k_{\text {tot }}=3.2 \times 10^{4}\right.$ and $8.3 \times 10^{3} \mathrm{M}^{-1} \mathrm{~s}^{-1}$, respectively), but not in a lipidic media ( $k_{t o t}=4.2 \times 10^{1}$ and $\approx 0 \mathrm{M}^{-1} \mathrm{~s}^{-1}$, respectively). From the kinetic point of view, the preferred mechanisms to trap the $\bullet \mathrm{OCH}_{3}$ radical are the diffusion-controlled transfer of the hydrogen atoms from the protonated pyridine, from the protonated amino group, and from the phenolic oxygen atom. Hydrogen-atom transfer reactions from the methylene groups in the $-\mathrm{CH}_{2} \mathrm{NH}_{3}$ and the $-\mathrm{CH}_{2} \mathrm{OH}$ ring substituents are also favorable pathways (rate constants in the order of $10^{4}-10^{6} \mathrm{M}^{-1} \mathrm{~s}^{-1}$ ). On the other hand, the formation of radical adducts on the aromatic carbon atoms adjacent to the pyridine nitrogen atom would be preferred when scavenging the $\bullet \mathrm{OOH}$ and $\bullet \mathrm{OOCH}_{3}$ radicals. These results add to our previous studies on the mechanisms by which PM inhibits post-Amadori reactions in the context of protein glycation by showing that, besides its strength as a metal chelator and its reactivity towards small carbohydrates and reactive carbonyl species, its ability to scavenge reactive oxygen species also plays a significant role.

Supplementary Materials: The following are available online at www.mdpi.com/xxx/s1, Table S1 : Imaginary frequencies and $\kappa$ values for TSs in water, Table S2: Imaginary frequencies and $\kappa$ values for TSs in pentyl ethanoate, Table S3: Gibbs free energies of activation for reactions in water, TableS4: Gibbs free energies of activation for reactions in pentyl ethanoate, Cartesian coordinates and figures of all located TSs.

Author Contributions: Conceptualization, J.F. and B.V.; methodology, R.R., C.C. and A.C.; formal analysis, R.R.; investigation, R.R., C.C. and A.C.; writing-original draft preparation, R.R.; writing-review and editing, J.O.-C., J.F., M.A. and R.C.; visualization, R.R.; supervision, J.F. and B.V.; project administration, J.F. and B.V.; and funding acquisition, J.F. and B.V.

Funding: This research was funded by the Ministerio de Economía y Competitividad (MINECO) and the European Fund for Regional Development (FEDER) (CTQ2014-55835-R), and by the Conselleria d'Educació, Cultura i Universitats (Ajuts a accions especials d'R+D AAEE49/2015).

Acknowledgments: The authors are grateful to "Consorci de Serveis Universitaris de Catalunya (CSUC)", the "Centro de Cálculo de Supercomputación de Galicia (CESGA)", and the "Centre de Tecnologies de la Informació (CTI) de la UIB" for providing access to their computational facilities. R.R. acknowledges his Ph.D. scholarship granted by the Spanish Ministerio de Educación, Cultura y Deporte (MECD) within the FPU program (FPU16/00785).

Conflicts of Interest: The authors declare no conflict of interest.

\section{Abbreviations}

The following abbreviations are used in this manuscript:

$\begin{array}{ll}\text { AGE } & \text { Advanced glycation end product } \\ \text { ROS } & \text { Reactive oxygen species } \\ \text { RCS } & \text { Reactive carbonyl species } \\ \text { NMR } & \text { Nuclear magnetic resonance } \\ \text { DFT } & \text { Density functional theory } \\ \text { PM } & \text { Pyridoxamine } \\ \text { PL } & \text { Pyridoxal } \\ \text { PN } & \text { Pyridoxine } \\ \text { PLP } & \text { Pyridoxal 5'-phosphate } \\ \text { QM-ORSA } & \text { Quantum mechanics-based test for overall free radical scavenging activity } \\ \text { TS } & \text { Transition state } \\ \text { SMD } & \text { Solvation Model based on the quantum mechanical charge Density of a solute molecule } \\ & \text { interacting with a continuum } \\ \text { HAT } & \text { Hydrogen atom transfer } \\ \text { RAF } & \text { Radical adduct formation } \\ \text { SET } & \text { Single electron transfer } \\ \text { TST } & \text { Transition state theory }\end{array}$




\section{References}

1. Bohlender, J.M.; Franke, S.; Stein, G.; Wolf, G. Advanced Glycation End Products and the Kidney. Am. J. Physiol. Ren. Physiol. 2005, 289, 645-659. [CrossRef] [PubMed]

2. Stitt, A.W. The Maillard Reaction in Eye Diseases. Ann. N. Y. Acad. Sci. 2005, 1043, 582-597. [CrossRef] [PubMed]

3. Kume, S.; Takeya, M.; Mori, T.; Araki, N.; Suzuki, H.; Horiuchi, S.; Kodama, T.; Miyauchi, Y.; Takahashi, K. Immunohistochemical and Ultrastructural Detection of Advanced Glycation End Products in Atherosclerotic Lesions of Human Aorta with a Novel Specific Monoclonal Antibody. Am. J. Pathol. 1995, 147, 654-667. [PubMed]

4. Thorpe, S.R.; Baynes, J.W. Maillard Reaction Products in Tissue Proteins: New Products and New Perspectives. Amino Acids 2003, 25, 275-281. [CrossRef] [PubMed]

5. Brownlee, M. Advanced Protein Glycosylation in Diabetes and Aging. Annu. Rev. Med. 1995, 46, $223-234$. [CrossRef] [PubMed]

6. Ulrich, P.; Cerami, A. Protein Glycation, Diabetes, and Aging. Recent. Prog. Horm. Res. 2001, 56, 1-21. [CrossRef]

7. Reynolds, T.M. Chemistry of Nonenzymatic Browning II. Adv. Food Res. 1965, 14, 167-283.

8. Rahbar, S.; Figarola, J.L. Inhibitors and Breakers of Advanced Glycation Endproducts (AGEs): A Review. Curr. Med. Chem. Immun. Enodcrinol. Metab. Agents 2002, 2, 135-161. [CrossRef]

9. Monnier, V.M. Intervention Against the Maillard Reaction in Vivo. Arch. Biochem. Biophys. 2003, 419, 1-15. [CrossRef]

10. Khalifah, R.G.; Baynes, J.W.; Hudson, B.G. Amadorins: Novel Post-Amadori Inhibitors of Advanced Glycation Reactions. Biochem. Biophys. Res. Commun. 1999, 257, 251-258. [CrossRef]

11. Snell, E.E. The Vitamin B6 Group. V. The Reversible Interconversion of Pyridoxal and Pyridoxamine by Transamination Reactions. J. Am. Chem. Soc. 1945, 67, 194-197. [CrossRef]

12. Degenhardt, T.P.; Alderson, N.L.; Arrington, D.D.; Beattie, R.J.; Basgen, J.M.; Steffes, M.W.; Thorpe, S.R.; Baynes, J.W. Pyridoxamine Inhibits Early Renal Disease and Dyslipidemia in the Streptozotocin-Diabetic Rat. Kidney Int. 2002, 61, 939-950. [CrossRef] [PubMed]

13. Murakoshi, M.; Tanimoto, M.; Gohda, T.; Hagiwara, S.; Ohara, I.; Toyoda, H.; Ishikawa, Y.; Horikoshi, S.; Tomino, Y. Pleiotropic Effect of Pyridoxamine on Diabetic Complications Via CD36 Expression in KK-Ay/Ta Mice. Diabetes Res. Clin. Pract. 2009, 83, 183-189. [CrossRef] [PubMed]

14. Stitt, A.; Gardiner, T.A.; Alderson, N.L.; Canning, P.; Frizzell, N.; Duffy, N.; Boyle, C.; Januszewski, A.S.; Chachich, M.; Baynes, J.W.; et al. The AGE Inhibitor Pyridoxamine Inhibits Development of Retinopathy in Experimental Diabetes. Diabetes 2002, 51, 2826-2832. [CrossRef] [PubMed]

15. Wu, E.; Liang, J.; Wu, M.; Chang, K. Pyridoxamine Prevents Age-Related Aortic Stiffening and Vascular Resistance in Association with Reduced Collagen Glycation. Exp. Gerontol. 2011, 46, 482-488. [CrossRef] [PubMed]

16. Adrover, M.; Vilanova, B.; Frau, J.; Muñoz, F.; Donoso, J. The Pyridoxamine Action on Amadori Compounds: A Reexamination of its Scavenging Capacity and Chelating Effect. Bioorg. Med. Chem. 2008, 16, 5557-5569. [CrossRef] [PubMed]

17. Thompson, D.M.; Balenovich, W.; Hornich, L.H.M.; Richardson, M.R. Reactions of Metal Ions With Vitamins. IV. The Crystal Structure of a Zinc Complex of Pyridoxamine (Vitamin B6). Inorg. Chim. Acta 1980, 46, 199-203. [CrossRef]

18. Ortega-Castro, J.; Adrover, M.; Frau, J.; Salvà, A.; Donoso, J.; Muñoz, F. DFT Studies on Schiff Base Formation of Vitamin B6 Analogues. Reaction Between a Pyridoxamine-Analogue and Carbonyl Compounds. J. Phys. Chem. A 2010, 114, 4634-4640. [CrossRef] [PubMed]

19. Adrover, M.; Vilanova, B.; Muñoz, F.; Donoso, J. A Comparative Study of the Chemical Reactivity of Pyridoxamine, Ac-Phe-Lys and Ac-Cys with Various Glycating Carbonyl Compounds. Amino Acids 2009, 36, 437-448. [CrossRef] [PubMed]

20. Voziyan, P.A.; Metz, T.O.; Baynes, J.W.; Hudson, B.G. A Post-Amadori Inhibitor Pyridoxamine Also Inhibits Chemical Modification of Proteins by Scavenging Carbonyl Intermediates of Carbohydrate and Lipid Degradation. J. Biol. Chem. 2002, 277, 3397-3403. [CrossRef] 
21. Chetykrin, S.; Zhang, W.; Hudson, B.D.; Serianni, A.S.; Voziyan, P.V. Pyridoxamine Protects Protein from Functional Damage by 3-Deoxyglucosone: Mechanism of Action for Pyridoxamine. Biochemistry 2008, 47, 997-1006.

22. Halliwell, B.; Gutteridge, J.M.C. Hydroxyl Radicals Assayed by Aromatic Hydroxylation and Deoxyribose Degradation. In Handbook of Methods for Oxygen Radical Research; Greenwald, R.A., Ed.; CRC Press: Boca Raton, FL, USA, 1986; pp. 177-180.

23. Voziyan, P.A.; Hudson, B.G. Pyridoxamine: The Many Virtues of a Maillard Reaction Inhibitor. Ann. N. Y. Acad. Sci. 2005, 1043, 807-816. [CrossRef] [PubMed]

24. Chetykrin, S.; Mathis, M.E.; Ham, A.J.L.; Hachey, D.L.; Hudson, B.G.; Voziyan, P.V. Propagation of Protein Glycation Damage Involves Modification of Tryptophan Residues Via Reactive Oxygen Species: Inhibition by Pyridoxamine. Free Radic. Biol. Med. 2008, 44, 1276-1285.

25. Jain, S.K.; Lim, G. Pyridoxine and Pyridoxamine Inhibits Superoxide Radicals and Prevents Lipid Peroxidation, Protein Glycosylation, and $\left(\mathrm{Na}^{+}+\mathrm{K}^{+}\right)$-ATPase Activity Reduction in High Glucose-Treated Human Erythrocytes. Free Rad. Biol. Med. 2001, 30, 232-237. [CrossRef]

26. Cao, G.; Alessio, H.M.; Cutler, R.G. Oxygen-Radical Absorbance Capacity Assay for Antioxidants. Free Radic. Biol. Med. 1993, 14, 303-311. [CrossRef]

27. Blois, M.S. Antioxidant Determinations by the Use of a Stable Free Radical. Nature 1958, 181, 1199-1200. [CrossRef]

28. Matxain, J.; Ristila, M.; Strid, A.; Eriksson, L.A. Theoretical Study of the Antioxidant Properties of Pyridoxine. J. Phys. Chem. A 2006, 110, 13068-13072. [CrossRef]

29. Matxain, J.; Ristila, M.; Strid, A.; Eriksson, L.A. Evidence of High $\bullet$ OH Radical Quenching Efficiency by Vitamin B6. J. Phys. Chem. B 2009, 113, 9629-9632. [CrossRef]

30. Galano, A.; Alvarez-Idaboy, J.R.; Francisco-Márquez, M.; Medina, M.E. A Quantum Chemical Study on the Free Radical Scavenging Activity of Tyrosol and Hydroxytyrosol. Theor. Chem. Acc. 2012, 131, 1-12. [CrossRef]

31. León-Carmona, J.; Galano, A. Is Caffeine a Good Scavenger of Oxygenated Free Radicals? J. Phys. Chem. B 2011, 115, 4538-4546. [CrossRef]

32. Galano, A.; Alvarez-Idaboy, J.R. Glutathione: Mechanism and Kinetics of Its Non-Enzymatic Defense Action Against Free Radicals. RSC Adv. 2011, 1, 1763-1771. [CrossRef]

33. Galano, A.; Francisco-Márquez, M.; Alvarez-Idaboy, J.R. Canolol: A Promising Chemical Agent Against Oxidative Stress. J. Phys. Chem. B 2011, 115, 8590-8596. [CrossRef] [PubMed]

34. Galano, A. On the Direct Scavenging Activity of Melatonin Towards Hydroxyl and a Series of Peroxyl Radicals. Phys. Chem. Chem. Phys. 2011, 13, 7147-7157. [CrossRef] [PubMed]

35. Ortega-Castro, J.; Adrover, M.; Frau, J.; Donoso, J.; Muñoz, F. Cu ${ }^{2+}$ Complexes of Some AGEs Inhibitors. Chem. Phys. Lett. 2009, 475, 277-284. [CrossRef]

36. Ortega-Castro, J.; Frau, J.; Casasnovas, R.; Fernández, D.; Donoso, J.; Muñoz, F. High- and Low-Spin Fe(III) Complexes of Various AGE Inhibitors. J. Phys. Chem. A 2012, 116, 2961-2971. [CrossRef] [PubMed]

37. Casasnovas, R.; Ortega-Castro, J.; Donoso, J.; Frau, J.; Muñoz, F. Theoretical Calculations of Stability Constants and $\mathrm{pK}_{\mathrm{a}}$ Values of Metal Complexes in Solution: Application to Pyridoxamine-Copper(II) Complexes and Their Biological Implications in AGE Inhibition. Phys. Chem. Chem. Phys. 2013, 15, 16303-16313. [CrossRef]

38. Adrover, M.; Vilanova, B.; Muñoz, F.; Donoso, J. Pyridoxamine, A Scavenger Agent of Carbohydrates. Int. J. Chem. Kinet. 2007, 39, 154-167. [CrossRef]

39. Adrover, M.; Vilanova, B.; Muñoz, F.; Donoso, J. Inhibition of Glycosylation Processes: The Reaction Between Pyridoxamine and Glucose. Chem. Biodivers. 2005, 2, 964-975. [CrossRef]

40. Rose, R.C.; Bode, A.M. Biology of Free Radical Scavengers. FASEB J. 1993, 7, 1135-1142. [CrossRef]

41. Galano, A.; Tan, D.X.; Reiter, R.J. Melatonin as a Naturall Ally Against Oxidative Stress: A Physicochemical Examination. J. Pineal Res. 2011, 51, 1-16. [CrossRef]

42. Galano, A.; Alvarez-Idaboy, J.R. A Computational Methodology for Accurate Prediction of Rate Constants in Solution: Application to the Assessment of Primary Antioxidant Activity. J. Comput. Chem. 2013, 34, 2430-2445. [CrossRef] [PubMed] 
43. Zhao, Y.; Schultz, N.E.; Truhlar, D.G. Design of Density Functionals by Combining the Method of Constraint Satisfaction with Parametrization for Thermochemistry, Thermochemical Kinetics, and Noncovalent Interactions. J. Chem. Theory Comput. 2006, 2, 364-382. [CrossRef] [PubMed]

44. Black, G.; Simmie, J.M. Barrier Heights for H-Atom Abstraction by $\mathrm{HO}_{2} \bullet$ from $n$-Butanol-A Simple Yet Exacting Test for Model Chemistries? J. Comput. Chem. 2009, 31, 1236-1248.

45. Furuncuoğlu, T.; Uğur, I.; Değirmenci, I.; Aviyente, V. Role of Chain Transfer Agents in Free Radical Polymerization Kinetics. Macromolecules 2010, 43, 1823-1835. [CrossRef]

46. Zhao, Y.; Truhlar, D.G. How Well Can New-Generation Density Functionals Describe the Energetics of Bond-Dissociation Reactions Producing Radicals? J. Phys. Chem. A 2008, 112, 1095-1099. [CrossRef] [PubMed]

47. Marenich, A.V.; Cramer, C.J.; Truhlar, D.G. Universal Solvation Model Based on Solute Electron Density and on a Continuum Model of the Solvent Defined by the Bulk Dielectric Constant and Atomic Surface Tensions. J. Phys. Chem. B 2009, 113, 6378-6396. [CrossRef] [PubMed]

48. Vilanova, B.; Adrover, M.; Muñoz, F.; Donoso, J. Photo-Induced Processes in Vitamin B6 Compounds. Chem. Biodivers. 2004, 1, 1073-1090. [CrossRef] [PubMed]

49. Okuno, Y. Theoretical Investigation of the Mechanism of the Baeyer-Villiger Reaction in Nonpolar Solvents. Chem. Eur. J. 1997, 3, 212-218. [CrossRef]

50. Benson, S.W. The Foundations of Chemical Kinetics; Krieger: Malabar, FL, USA, 1982.

51. Eckart, C. The Penetration of a Potential Barrier by Electrons. Phys. Rev. 1930, 35, 1303-1309. [CrossRef]

52. Brown, R.L. A Method of Calculating Tunneling Corrections for Eckart Potential Barriers. J. Res. Natl. Bur. Stand. 1981, 86, 357-359. [CrossRef]

53. Collins, F.C.; Kimball, G.E. Diffusion-Controlled Reaction Rates. J. Colloid Sci. 1949, 4, 425-437. [CrossRef]

54. Smoluchowski, M.Z. Attempt for a Mathematical Theory of Kinetic Coagulation of Colloid Solutions. J. Phys. Chem. 1917, 92, 129-168.

55. Stokes, G.G. Mathematical and Physical Papers; Cambridge University Press: Cambridge, UK, 1903; Volume 3, p. 55.

56. Einstein, A. Motion of Suspended Particles in Stationary Liquids Required from the Molecular Kinetic Theory of Heat. Ann. Phys. 1905, 17, 549-560. [CrossRef]

57. Frisch, M.J.; Trucks, G.W.; Schlegel, H.B.; Scuseria, G.E.; Robb, M.A.; Cheeseman, J.R.; Scalmani, G.; Barone, V.; Mennucci, B.; Petersson, G.A.; et al. Gaussian09, Revision D.01; Gaussian, Inc.: Wallingford, CT, USA, 2013.

58. Galano, A.; Martínez, A. Capsaicin, a Tasty Free Radical Scavenger: Mechanism of Action and Kinetics. J. Phys. Chem. B 2012, 116, 1200-1208. [CrossRef] [PubMed]

59. Amić, A.; Marković, Z.; Klein, E.; Dimitrić Marković, J.M.; Milenković, D. Theoretical Study of the Thermodynamics of the Mechanisms Underlying Antiradical Activity of Cinnamic Acid Derivatives. Food Chem. 2018, 246, 481-489. [CrossRef] [PubMed]

60. Galano, A.; Francisco-Marquez, M. Reactions of OOH Radical with $\beta$-Carotene, Lycopene, and Torulene: Hydrogen Atom Transfer and Adduct Formation Mechanisms. J. Phys. Chem. B 2009, 113, 11338-11345. [CrossRef] [PubMed]

61. Galano, A.; Francisco-Marquez, M. Peroxyl-Radical-Scavenging Activity of Garlic: 2-Propenesulfenic Acid versus Allicin. J. Phys. Chem. B 2009, 113, 16077-16081. [CrossRef] [PubMed]

62. Burton, G.W.; Doba, T.; Gabe, E.; Hughes, L.; Lee, F.L.; Prasad, L.; Ingold, K.U. Autoxidation of Biological Molecules. 4. Maximizing the Antioxidant Activity of Phenols. J. Am. Chem. Soc. 1985, 107, 7053-7065. [CrossRef]

63. Galano, A.; León-Carmona, J.R.; Alvarez-Idaboy, J.R. Influence of the Environment on the Protective Effects of Guaiacol Derivatives against Oxidative Stress: Mechanisms, Kinetics, and Relative Antioxidant Activity. J. Phys. Chem. B 2012, 116, 7129-7137. [CrossRef]

64. Galano, A.; Alvarez-Idaboy, J.R.; Francisco-Márquez, M. Physicochemical Insights on the Free Radical Scavenging Activity of Sesamol: Importance of the Acid/Base Equilibrium. J. Phys. Chem. B 2011, 115, 13101-13109. [CrossRef]

65. Booth, A.A.; Khalifah, R.G.; Hudson, B.G. Thiamine Pyrophosphate and Pyridoxamine Inhibit the Formation of Antigenic Advanced Glycation End-Products: Comparison with Aminoguanidine. Biochem. Biophys. Res. Commun. 1996, 220, 113-119. [CrossRef] [PubMed] 
66. Stocker, P.; Lesgards, J.F.; Vidal, N.; Chalier, F.; Prost, M. ESR Study of a Biological Assay on Whole Blood: Antioxidant Efficiency of Various Vitamins. Biochim. Biophys. Acta Gen. Subj. 2003, 1621, 1-8. [CrossRef]

67. Merigliano, C.; Mascolo, E.; Burla, R.; Saggio, I.; Verni, F. The Relationship Between Vitamin B6, Diabetes and Cancer. Front. Genet. 2018, 9, 1-5. [CrossRef] [PubMed]

68. Voziyan, P.A.; Khalifah, R.G.; Thibaudeau, C.; Yildiz, A.; Jacob, J.; Serianni, A.S.; Hudson, B.G. Modification of Proteins In Vitro by Physiological Levels of Glucose. J. Biol. Chem. 2003, 278, 46616-46624. [CrossRef] [PubMed]

69. Nagaraj, R.H.; Sarkar, P.; Mally, A.; Biemel, K.M.; Lederer, M.O.; Padayatti, P.S. Effect of Pyridoxamine on Chemical Modification of Proteins by Carbonyls in Diabetic Rats: Characterization of a Major Product from the Reaction of Pyridoxamine and Methylglyoxal. Arch. Biochem. Biophys. 2002, 402, 110-119. [CrossRef]

70. Amarnath, V.; Amarnath, K.; Amarnath, K.; Davies, S.; Roberts, L.J. Pyridoxamine: An Extremely Potent Scavenger of 1,4-Dicarbonyls. Chem. Res. Toxicol. 2004, 17, 410-415. [CrossRef] [PubMed]

71. Ehrenshaft, M.; Jenns, A.E.; Chung, K.R.; Daub, M.E. SOR1, a Gene Required for Photosensitizer and Singlet Oxygen Resistance in Cercospora Fungi, Is Highly Conserved in Divergent Organisms. Mol. Cell 1998, 1, 603-609. [CrossRef]

72. Bilski, P.; Li, M.Y.; Ehrenshaft, M.; Daub, M.E.; Chignell, C.F. Vitamin B 6 (Pyridoxine) and Its Derivatives Are Efficient Singlet Oxygen Quenchers and Potential Fungal Antioxidants. Photochem. Photobiol. 2000, 71, 129-134. [CrossRef]

73. Denslow, S.A.; Walls, A.A.; Daub, M.E. Regulation of Biosynthetic Genes and Antioxidant Properties of Vitamin $B_{6}$ Vitamers During Plant Defense Responses. Physiol. Mol. Plant Pathol. 2005, 66, $244-255$. [CrossRef]

74. Danon, A.; Miersch, O.; Felix, G.; Camp, R.G.L.; Apel, K. Concurrent Activation of Cell Death-Regulating Signaling Pathways by Singlet Oxygen in Arabidopsis Thaliana. Plant J. 2005, 41, 68-80. [CrossRef]

75. Anand, S.S. Protective Effect of Vitamin $\mathrm{B}_{6}$ in Chromium-Induced Oxidative Stress in Liver. J. Appl. Toxicol. 2005, 25, 440-443. [CrossRef] [PubMed]

76. Gliszczyńska-Świglo, A. Antioxidant Activity of Water Soluble Vitamins in the TEAC (Trolox Equivalent Antioxidant Capacity) and the FRAP (Ferric Reducing Antioxidant Power) Assays. Food Chem. 2006, 96, 131-136. [CrossRef]

77. Matxain, J.M.; Ristilä, M.; Strid, A.; Eriksson, L.A. Theoretical Study of the Reaction of Vitamin $\mathrm{B}_{6}$ with ${ }^{1} \mathrm{O}_{2}$. Chem. Eur. J. 2007, 13, 4636-4642. [CrossRef] [PubMed]

78. Škorňa, P.; Rimarčíc, J.; Poliak, P.; Lukeš, V.; Klein, E. Thermodynamic Study of Vitamin B 6 Antioxidant Potential. Comput. Theor. Chem. 2016, 1077, 32-38. [CrossRef]

79. Abdullah, K.M.; Qais, F.A.; Ahmad, I.; Hasan, H.; Naseem, I. Study of Pyridoxamine Against Glycation and Reactive Oxygen Species Production in Human Serum Albumin as Model Protein: An In Vitro \& Ex Vivo Approach. Int. J. Biol. Macromol. 2018, 120, 1734-1743. [PubMed]

(C) 2019 by the authors. Licensee MDPI, Basel, Switzerland. This article is an open access article distributed under the terms and conditions of the Creative Commons Attribution (CC BY) license (http:/ / creativecommons.org/licenses/by/4.0/). 